\title{
An Industrial Analysis of Trade Creation and Diversion Effects of NAFTA
}

\author{
David Karemera \\ South Carolina State University \\ Kalu Ojah \\ Saint Louis University
}

\begin{abstract}
Welfare effects of economic integration are often studied with aggregate data, and as such provide limited insights about the effects of trade pacts to individual economic agents in the free trade area. In this study a threedigit disaggregated commodity/ industry data grouped under the Standard International Trade Classification is used to empirically assess the economic benefits of the North American F ree Trade Agreement ( NAFTA). I mport demand elasticities from a dynamic demand model were used to estimate both trade creation and trade diversion effects of removing all tariff barriers from among NAFTA countries US, Canada and M exico. Results show that US imports of crude oil and petrole um products from Canada and most US impor ts from M exico are more sensi tive to domestic prices than to bilateral import prices. Further, results indicate
\end{abstract}


that US will ben efit the most from the initial trade effects of NAFTA, while M ex ico will benefit the least. Specifically, US expor ters of automatic data processing equipment, and pulp and waste paper products will benefit the most from increased trade with NAFTA countries. M exican expor ters of crude oil, and veg etables and fresh produce; and Canadian exporters of paper and paperboard products will be the most beneficiaries of NAFTA among exporters in these respective countries. (JEL Classification: F 1, F 2)

\section{Introduction}

The North American Free Trade Agreement (NAFTA) is expected to offer benefits to several sectors of the US, Canadian, and M exican economies. Both producers and consumers in the NAFTA countries should experience economic changes attributable to free trade. Studies that have tried to estimate potential effects of economic integration used aggregate or semi-aggregate data, and as a result, were unable to address the specific impacts of integration at the industry level <Wonnacott and Wonnacott [1982]; J acobs [1991]; Yamazawa [1992]; and Brown [1992]). Karemera and Koo [1994] used a one-digit Standard International Trade Classification (SITC) data, which is more aggregated than the three-digit SITC data used in this study. Thus, this study assesses more comprehensively the impacts of NAFTA at the industry level than other studies of its kind 〈e.g., Brown, Deardorff and Stern [1992]; Klein and Salvatore [1994]; Doroodian, B oyd and Piracha [1994]; and Casario [1996] $\rangle$. Additionally, we employed a partial equilibrium model that specifically indicates whether trade expansion associated with NAFTA stems from trade creation (TC) or is due to trade diversion (TD). ${ }^{1}$ In other words, our model provides results that inform firms in analyzed industries as to whether NAFTA would affect them favorably or 
sively to the manufacturing industry. Thus, we provide pertinent information that can aid economic agents in several more industries within NAFTA countries to restructure and reallocate resources in ways that optimize production and output.

When a country embarks on a free trade pact with a limited number of countries, two possible outcomes are common: Trade creation (TC) and/ or trade diversion (TD) 〈Balassa [1975]〉. TC occurs when lower priced imports from a country's free trade partners replace higher priced domestic substitutes. TD occurs when restricted imports from nonbeneficiaries are displaced by imports from beneficiaries.

Verdoorn [1960, 1972], and B aldwin and M urray [1977] provide methods for estimating potential TC and TD that are due to economic integration. Both methods compute TC under the assumption that imports are perfect substitutes for domestic production, as such they yield identical TC estimates. However, the two methods compute TD under different assumptions. Consequently, they yield different estimates of TD. Thus, the accuracy of TD estimates has been an issue 〈Sawyer and Sprinkle [1989]〉. Baldwin and $M$ urray compute TD as the ratio of imports from nonbeneficiaries to domestic production, while Verdoorn computes TD as the ratio of beneficiary's imports to total domestic imports. Pomfret [1986] suggests that B aldwin and M urray's method yields unreasonably low estimates and thus recommends Verdoorn's method, which is used in our analysis, as superior.

NAFTA countries' industries that recorded the highest trade volumes (according to the United $\mathrm{N}$ ations' records) were selected to calculate individual industry's potential trade expansion following the removal of tariff and nontariff barriers from among NAFTA countries. We use price elasticities of import estimates to derive industry level impacts and compare the potential gains from free trade between and among NAFTA countries. Trad- 
countries. For instance, we found that some US imports from both Canada and $M$ exico are more competitive in import markets while some are more competitive in domestic markets. We further document that NAFTA elicits trade expansion for NAFTA countries, and that the expansion is due more to $T C$ than to TD.

Section II provides a summary of key provisions of NAFTA. This section also presents import demand specification and import price elasticities estimation. Section IV describes procedures used to compute TC and TD. Section $\mathrm{V}$ discusses the estimated results and the relative gains of free trade for specific industries in the US, Canada, and M exico. The last section summarizes and concludes the study.

\section{Major Provisions of the North American Free Trade Agreement}

NAFTA was signed in December 1992, and after ratification by the US Congress and the governing bodies of Canada and M exico, it became effective in J anuary, 1994. NAFTA provides participants the removal of barriers to trade in goods and services. It promotes fair competition, fairly unrestricted investment opportunities, and protection of intellectual property rights. Specifically, duties on automobiles and computers were immediately removed. Duties on all other goods were scheduled to be eliminated over staggered 5-, 10- and 15-year intervals. As of J anuary 1994, nontariff barriers, such as quota and licensing arrangements were proscribed.

The removal of M exican duties off of US and Canadian goods, for example, should have a major impact on the competitiveness of M exican importsubstitutes. The duty-free trade impact on US goods should be more significant than that on Canadian goods. This difference is due to the fact M exican tariffs on imports from the US range from $10 \%$ for some goods to as high as 
forward-looking context, wherein they gauge the effects of other Western Hemisphere countries' ascension to NAFTA. They show how US trade volume would increase as additional western hemisphere countries joined NAFTA, as well as how the overall trade in the region would increase proportionately with the ascension of other countries.

Import-competitors in M exico (e.g., manufacturing firms) should experience some trade (profit) reduction in the early stages of NAFTA. Added pressure in the form of product price competition from US and Canadian produced imports, would force the reallocation of Mexico's scarce resources into productions where M exico has comparative advantage over the US and Canada. On the other hand, the US average tariff on M exican goods is about $4.6 \%$ Therefore, removing US tariffs on M exican goods should not elicit significant changes in M exican expor ts to the US.

Table 1 shows the largest bilateral trade volumes between member countries of NAFTA by selected commodities. From 1990 to 1992 the average dollar value of selected US imports from Canada was $\$ 18.61$ billion (which constitutes $19 \%$ of total US imports from (anada) and the average from M exico was $\$ 7.41$ billion ( $23 \%$ of US total imports from M exico). The average Canadian imports of the selected commodity groups from the US was $\$ 2.25$ billion, while that of M exican imports from the US, for the same period, was $\$ 2.37$ billion. For examples, US imports of Crude Oil from Canada accounted for about $5 \%$ of US total imports from Canada; and M exican crude oil, which was the largest US imports from M exico accounted for $14 \%$ of US total imports from M exico. The largest M exican imports from the US and Canada were Refined Petroleum products, and Passenger M otor Vehicles; and Paper and Paperboard products, respectively. The largest Canadian imports from the US were Vegetables and Fresh produce, and Paper and Paperboard. Interestingly, some of the sizeable Canadian imports from 
Table 1

\section{B ilateral Trade Volume by Commodity Groups for the United States, Canada and Mexico}

\section{A. Selected US Imports from Canada (in 1,000 US \$)}

\begin{tabular}{|l|r|r|r|r|l|}
\hline \multicolumn{1}{|c|}{ Commodity groups (SITC) } & \multicolumn{1}{|c|}{1990} & \multicolumn{1}{|c|}{1991} & \multicolumn{1}{c|}{1992} & \multicolumn{1}{c|}{ M ean } & Ratio $^{\mathrm{a}}$ \\
\hline Vegetables Fresh etc (054) & 156,409 & 135,563 & 124,303 & 138,258 & .010 \\
Wood shaped sleepers (248) & $2,950,035$ & $2,887,892$ & $3,730,063$ & $3,189,330$ & .030 \\
Pulp and waste paper (251) & $2,662,976$ & $1,983,148$ & $1,894,059$ & $2,180,061$ & .020 \\
Crude petroleum (333) & $4,704,218$ & $5,214,462$ & $5,488,354$ & $5,135,678$ & .050 \\
Petroleum product, ref. (334) & $2,108,522$ & $1,974,720$ & $1,681,409$ & $1,911,550$ & .020 \\
Paper and Paperboard (641) & $6,320,298$ & $6,072,073$ & $5,802,471$ & $6,064,947$ & .060 \\
Television Receivers (761) & 133,424 & 148,016 & 153,500 & 144,980 & .001 \\
SUBTOTAL & $19,035,882$ & $18,415,874$ & $18,874,159$ & $18,764,804$ & .195 \\
Total US import from Canada & $\mathbf{9 3 , 6 8 8 , 8 6 4}$ & $\mathbf{9 3 , 5 8 5 , 0 1 3}$ & $101,241,410$ & $\mathbf{9 6 , 1 7 1 , 7 6 2}$ & .182 \\
Total U.S. Imports from the World & $\mathbf{5 1 7 , 5 2 4 , 4 6 6}$ & $\mathbf{5 0 8 , 9 4 4 , 0 8 0}$ & $\mathbf{5 5 3 , 4 9 6 , 5 2 1}$ & $\mathbf{5 2 6 , 6 5 5 , 0 2 2}$ & \\
\hline
\end{tabular}

\section{B. Selected U.S. Imports from Mexico (in 1,000 US \$)}

\begin{tabular}{|l|r|r|r|r|c|}
\hline \multicolumn{1}{|c|}{ Commodity groups (SITC) } & \multicolumn{1}{|c|}{1990} & \multicolumn{1}{c|}{1991} & \multicolumn{1}{c|}{1992} & \multicolumn{1}{c|}{ M ean } & Ratio $^{\mathrm{a}}$ \\
\hline Vegetables Fresh etc (054) & 977,969 & 867,630 & 76,723 & 871,074 & .030 \\
Wood shaped sleepers (248) & 105,740 & 123,315 & 155,512 & 128,189 & .004 \\
Pulp and waste paper (251) & 1,890 & 1,511 & 5,146 & 2,849 & .000 \\
Crude petroleum (333) & $4,965,535$ & $4,499,854$ & $4,496,081$ & $4,653,823$ & .140 \\
Petroleum product, ref. (334) & 315,671 & 312,792 & 309,914 & 312,792 & .009 \\
Paper and Paperboard (641) & 97,636 & 48,602 & 61,560 & 69,266 & .002 \\
Pass motor veh. exc.. bus (781) & $2,185,371$ & $2,603,478$ & 263,103 & $1,683,894$ & .050 \\
SUBTOTAL & $8,649,812$ & $8,457,182$ & $5,368,039$ & $7,721,887$ & .235 \\
Total US Imports from M exico & $30,769,707$ & $31,771,519$ & $35,865,045$ & $32,802,090$ & .062 \\
Total US Imports from the W orld & $\mathbf{5 1 7 , 5 2 4 , 4 6 6}$ & $\mathbf{5 0 8 , 9 4 4 , 0 8 0}$ & $\mathbf{5 5 3 , 4 9 6 , 5 2 1}$ & $\mathbf{5 2 6 , 6 5 5 , 0 2 2}$ & \\
\hline
\end{tabular}

\section{Selected Canadian Imports from the US (in 1,000 US \$)}

\begin{tabular}{|l|l|l|l|l|l|}
\hline Commodity groups (SITC) & 1990 & 1991 & 1992 & M ean & Ratio $^{\mathrm{a}}$ \\
\hline
\end{tabular}




\section{Selected Canadian Imports from Mexico (in 1,000 US \$)}

\begin{tabular}{|l|r|r|r|r|l|}
\hline \multicolumn{1}{|c|}{ Commodity groups (SITC) } & \multicolumn{1}{|c|}{1990} & \multicolumn{1}{|c|}{1991} & \multicolumn{1}{c|}{1992} & M ean & Ratio $^{\text {a) }}$ \\
\hline Paper and paperboard (614) & 4,377 & 509 & 1,271 & 2,052 & .001 \\
Internal combust. pstn engin. (713) & 260,795 & 193,121 & 116,437 & 190,118 & .090 \\
Automatic data proc. equip. (752) & 143,523 & 106,230 & 85,670 & 111,808 & .060 \\
Electric. distribt. equip. nes. (773) & 81,208 & 97,678 & 113,743 & 97,543 & .050 \\
Electric. mach. appart. nes. (778) & 35,410 & 49,157 & 63,171 & 49,246 & .020 \\
Goods spcl. transport veh. (782) & 19,174 & 35,999 & 59,631 & 38,268 & .020 \\
SUBTOTAL & 544,487 & 482,694 & 439,923 & 489,035 & .241 \\
Total Canadian imports from M exico & $1,482,177$ & $2,247,377$ & $2,295,074$ & $2,008,209$ & .020 \\
Total Canadian imports from the World & $116,453,476$ & $118,088,355$ & $122,583,705$ & $119,041,845$ & \\
\hline
\end{tabular}

\section{E. Selected Mexican Imports from the US (in 1,000 US \$)}

\begin{tabular}{|l|r|r|r|r|r|}
\hline \multicolumn{1}{|c|}{ Commodity groups (SITC) } & \multicolumn{1}{c|}{1990} & \multicolumn{1}{c|}{1991} & \multicolumn{1}{c|}{1992} & \multicolumn{1}{c|}{ M ean } & Ratio $^{\text {a) }}$ \\
\hline Vegetables Fresh etc (054) & 129,229 & 55,740 & 66,155 & 83,708 & .003 \\
Wood shaped sleepers (248) & 150,375 & 201,405 & 261,442 & 204,407 & .010 \\
Pulp and waste paper (251) & 317,318 & 284,465 & 295,641 & 299,141 & .010 \\
Petroleum product, ref. (334) & 537,197 & 625,979 & 808,476 & 657,217 & .020 \\
Paper and Paperboard (641) & 195,762 & 260,763 & 352,369 & 269,631 & .010 \\
Automatic data proc. equip. (752) & 327,253 & 426,076 & 559,591 & 437,640 & .010 \\
Television receivers etc. (761) & 121,226 & 118,656 & 141,563 & 127,148 & .004 \\
Goods, spcl. transport veh. (782) & 80,356 & 113,605 & 141,720 & 111,893 & .003 \\
Pass. motor veh. exc. bus (781) & 182,642 & 168,223 & 120,337 & 180,453 & .010 \\
SUBTOTAL & $2,041,358$ & $2,254,912$ & $2,747,294$ & $2,371,238$ & .070 \\
Total M exican Imports from US & $27,449,501$ & $32,252,759$ & $39,651,431$ & $33,084,563$ & .765 \\
Total M exican Imports from the World & $29,559,541$ & $38,121,500$ & $61,924,225$ & $43,235,089$ & \\
\hline
\end{tabular}

\section{F. Selected Mexican Imports from Canada (in 1,000 US \$)}

\begin{tabular}{|l|r|r|r|r|c|}
\hline \multicolumn{1}{|c|}{ Commodity groups (SITC) } & 1990 & \multicolumn{1}{c|}{1991} & \multicolumn{1}{c|}{1992} & \multicolumn{1}{c|}{ M ean } & Ratio $^{\text {a) }}$ \\
\hline Paper and paperboard (641) & 17,645 & 96,616 & 27,929 & 47,397 & .080 \\
Internal combust. pstn. engin. (713) & 15,460 & 4,602 & 7,941 & 9,334 & .010 \\
\hline
\end{tabular}


tries are $4.6 \%$ for the US, $12.38 \%$ for Canada, and $20 \%$ for M exico. N ontariff trade restrictions, such as quota and voluntary import or export restrictions have only been sparingly used among NAFTA countries. Thus, the removal of tariffs alone, which form the basis for our analysis, would lead to the expansion of both individual commodities and overall trade volumes.

\section{Trade Creation and Trade Diversion Effects of NAFTA}

The effects of removing or lowering trade barriers between two trade partners can be evaluated by estimating trade creation (TC) and trade diversion (TD) for each commodity for each of the participating countries. M ost researchers use either the Baldwin and Murray [1977] method or Verdoom's [1972] method to estimate TC and TD. The Baldwin and Murray methods for computing TC and TD effects are as stated in equations \#3 and $\#$ \#, respectively.

$$
\begin{aligned}
& \mathrm{TC}_{\mathrm{i}}=\mathrm{M}_{\mathrm{i}} \eta_{\mathrm{i}}\left(\delta \mathrm{t}_{\mathrm{i}} / 1+\mathrm{t}_{\mathrm{i}}\right) \\
& \mathrm{TD}_{\mathrm{i}}=\mathrm{TC}_{\mathrm{i}}\left(\mathrm{MN}_{\mathrm{i}} / \mathrm{V}_{\mathrm{i}}\right),
\end{aligned}
$$

where:

$\mathrm{TC}_{\mathrm{i}}=$ trade creation effects for a selected commodity $\mathrm{i}$ in the NAFTA country,

$M_{i}=$ initial level of imports of commodity i from another NAFTA county,

$\eta_{i}=$ price elasticity of import demand for commodity $i$,

$\delta_{i}=$ level of tariff cut in commodity $i$ by the NAFTA country,

$t_{i}=$ initial level of tariff on commodity $i$ in the NAFTA countr $y$,

$\mathrm{TD}_{\mathrm{i}}=$ trade diversion effects for a commodity $\mathrm{i}$ in the NAFTA country, 
where $M_{i} /\left(M N_{i}+M_{i}\right)$ is the ratio of import i from another NAFTA country to the evaluated NAFTA country's total imports of a commodity group i. All other individual variables remain as described in equations \#3 and \#4 above.

For the empirical implementation of the integration theory, Baldwin and Murray's method requires each commodity group's domestic production, which is usually unavailable. Hence, the Verdoorn formula, which does not have a similar input requirement problem, is predominantly used to compute TD 〈Sawyer and Sprinkle [1989]〉.

\section{Specification of the Import Demand Behavior and Seemingly Unrelated Regression Equations (SURE)}

The classical estimation of imports demand function for a country has traditionally been based on the following assumptions. Imports are directly proportional to the importing country's national income (or GNP), is inversely proportional to imports prices, and is directly proportional to prices of import-competing commodities. Hence, the following specification of the static classical imports demand model provides a basis for this study:

$$
\ln Q_{i t}=\lambda_{0}+\lambda_{1} \operatorname{lnM} P_{i t}+\lambda_{2} \operatorname{lnD} P_{i t}+\lambda_{3} \ln W P_{i t}+\lambda_{4} \ln Y_{t}+\ln e_{i t}
$$

where $Q_{i t}$ is, for instance, the dollar volume of US imports from Canada or M exico; alternatively, it could represent Mexican imports from the US or Canada; $M P_{i t}$ is the bilateral unit value index of imports; $D P_{i t}$ is the domestic wholesale price index of the importing country; $W P_{i t}$ is the imports' multilateral or world price index; $Y_{t}$ is a measure of the importing country's national income. The subscript $i$ identifies the selected commodity, which is alternatingly subbed into the model for each of the NAFTA countries. The subscript 
commodity markets. A specification that allows for different import behaviors is most amenable to capturing the potential impacts of NAFTA for each traded commodity. Such specification is appealing because each commodity or industry faces different levels of competition (i.e., different commodities tend to be traded under different market structures), and each faces different resource endowment. Zellner's [1962] SURE is an efficient estimation technique that accounts for cross-industry correlation and variation. SURE estimation is also motivated by the increase degrees of freedom associated with a SURE system. Furthermore, since most imports exhibit dynamic behaviors, demand specifications should also be modified to reflect the dynamic behavior of imports. To incorporate dynamism in equation \#1, a stock adjustment mechanism is assumed for the imports demand function 〈e.g., see Karemera and Koo [1994]〉. For a complete derivation of dynamic imports demand functions, see Goldstein and Khan [1978] and Koo et al. [1991]. For example, a dynamic model applied to quarterly data would require the use of three quarterly dummy variables, $D_{2 t}, D_{3 t}$ and $D_{4 t}$, which capture the seasonality pattern in import behavior across NAFTA countries.

Trade data used in this study are classified under SITC at the three-digit level. Given there are numerous commodities involved in trade at this level of disaggregation, we selected the ten most traded commodities among NAFTA countries. The SURE system in a dynamic framework includes ten equations, if all required variables were available, each by commodity and by country. For each country the dynamic import demand in a SURE system is specified as:

$$
\begin{aligned}
\ln Q_{i t}= & \beta_{0}+\beta_{1} \ln M P_{i t}+\beta_{2} \ln D P_{i t}+\beta_{3} \ln W P_{i t}+\beta_{4} \ln Y_{t} \\
& +\beta_{5} D_{2 t}+\beta_{6} D_{3 t}+\beta_{7} D_{4 t}+\beta_{8} \ln Q_{i t-1}+\ln U_{i t}
\end{aligned}
$$


Wang et al [1981].

Before discussing the estimation results, some remarks about expected signs of estimated coefficients are in order. A rise in an importing country's income should increase the levels of imports. The import price coefficient is expected to be negatively related to imports. A rise in domestic price index should lead to an increase in imports as lower priced imports displace high cost domestic output. An increase in the world price index should lead to an increase in bilateral NAFTA imports as substitutes of high priced competing imports from the rest of world. Conversely, an increase in the world price index can lead to a decrease in bilateral imports if the world price index is higher than the domestic price index.

\section{Results and Interpretations}

The sampling period for the US, Canadian, and M exican quarterly trade is 1980.I to 1993.I. Quantities and dollar values of traded goods were obtained from the U nited Nations Statistical Division Office and from Statistics Canada. Unit prices were obtained by dividing trade dollar values by trade quantities. Domestic wholesale price indexes, multilateral price indexes and GNPs were obtained from the International Financial Statistics of the IMF. The ten highest trade volume commodities for each of the NAFTA countries were selected. However, data limitations forced us to reduce the number of estimable equations to six or eight, and data limitation also forced the use of some commodity groups that were not among the ten largest trade volumes for the Canada-M exico analyzes. The automobile trade between the US and Canada was excluded because there has been a free movement of automobiles between both countries under the 1965 Auto Pact. However, the auto trade with M exico is included in the analysis. 
suggesting that the estimated model is stable. Further, for all the SURE models for each participating country, most of the lagged dependent variables are significant at the $5 \%$ level. The seasonality variables indicate that most imports exhibit seasonal behavior. Additionally, results suggest that imports demand functions exhibit strong dynamism and seasonality, except for notable commodity groups, such as US Crude Oil and Petroleum imports from Canada.

The estimates of income elasticities of imports are used to assess the income effects on imports. Results for most commodities indicate that increase in imports due to increase in income alone, would be largest for the US because income elasticities for the US are larger than those for Canada and Mexico for most commodities. M exico's record of least increase in imports due to increase in income alone, as shown by all income elasticities being less than unity, reflects the lower income-level status of $M$ exico relative to other NAFTA members. This finding also contrasts with those of past studies that used aggregate or semi-aggregate data. M oreover, using industries identified by the 3-digits SITC, shows that specific commodities are relatively more competitive domestically while others are more competitive internationally. This behavior is a reflection of both the relative size of internal markets, and of the appeal and competitiveness of specific industry products.

Tables 2, 3, 4 and 5 report estimated results by commodity model and NAFTA country. For the US models of imports from Canada and M exico, most variables have the expected signs and are significantly different from zero at the $5 \%$ level. The system's $R^{2}$ is 0.900 for US imports from Canada and 0.924 for US imports from M exico; suggesting that included variables explain most of the variation in imports. A similar conclusion applies to the Canadian model of imports from the US. The system's $R^{2}$ is 0.946 , implying 


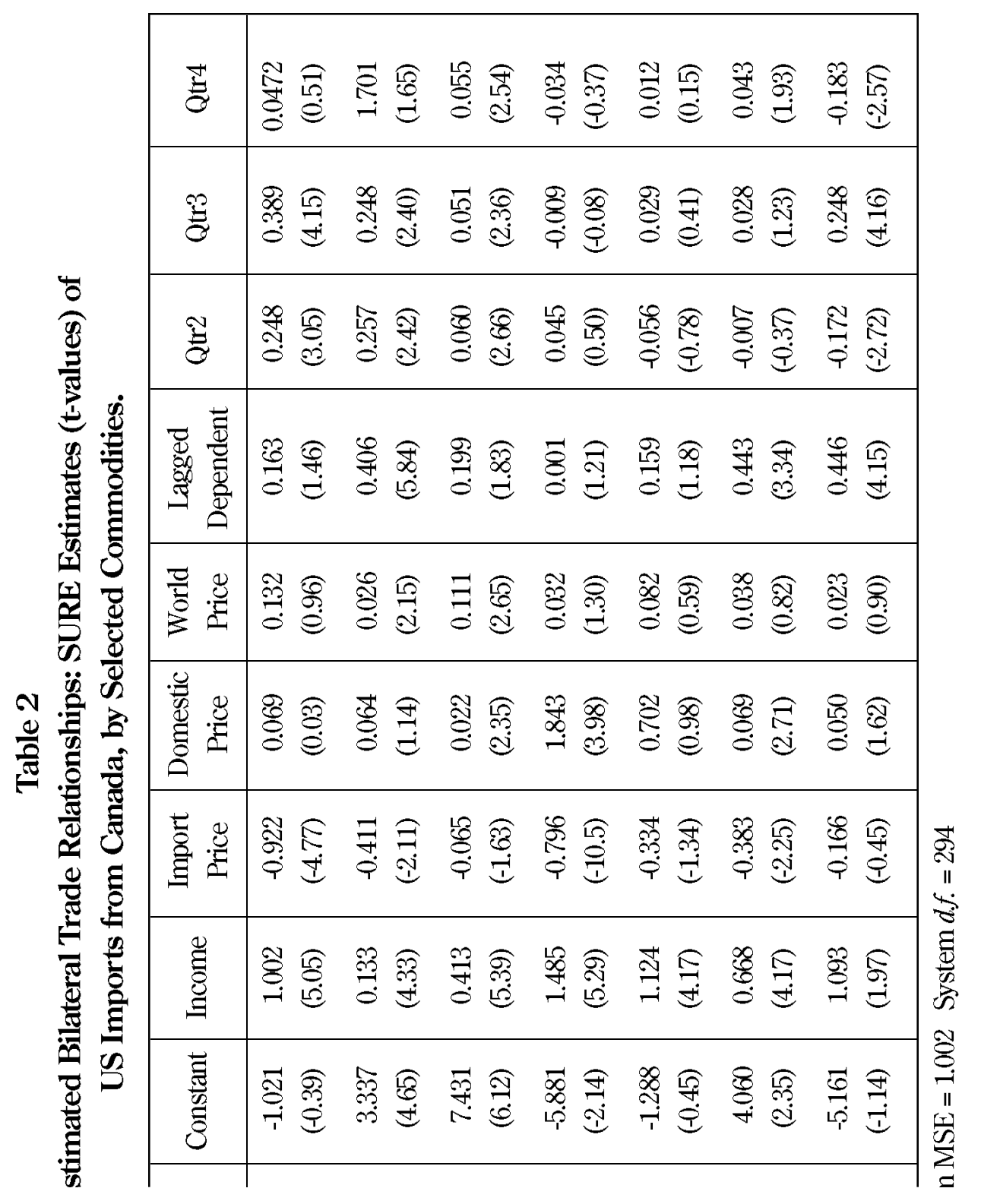




\begin{tabular}{|c|c|c|}
\hline \multirow{10}{*}{ 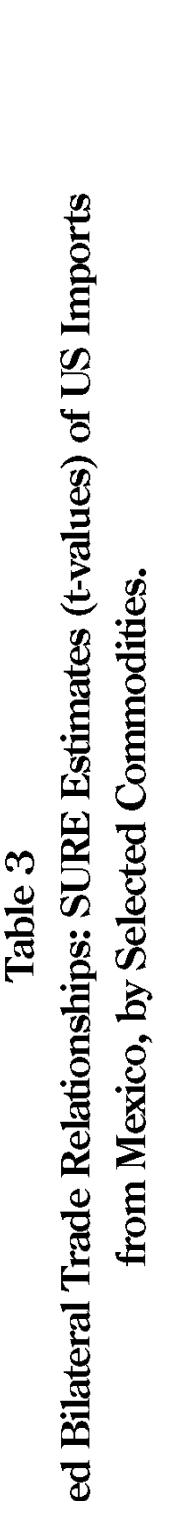 } & $\overrightarrow{0}$ & 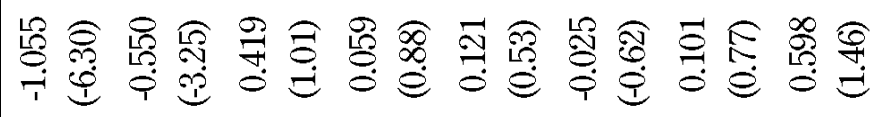 \\
\hline & $\dddot{0}$ & 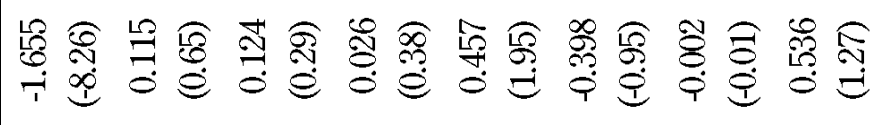 \\
\hline & $\stackrel{y}{\sigma}$ & 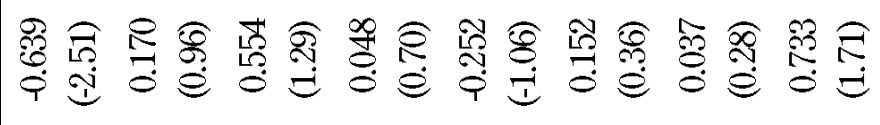 \\
\hline & 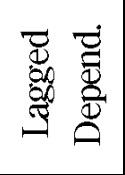 & 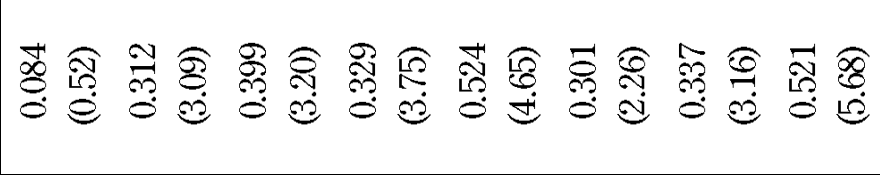 \\
\hline & 를 & 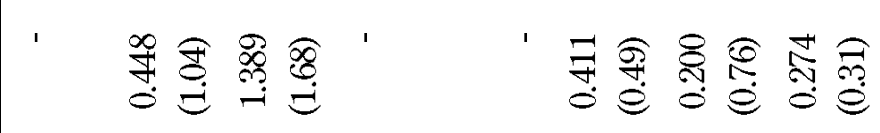 \\
\hline & 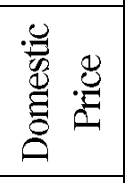 & 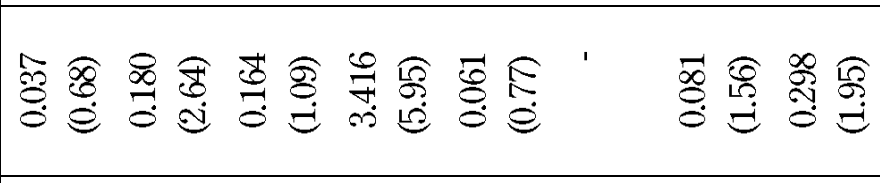 \\
\hline & 总. & 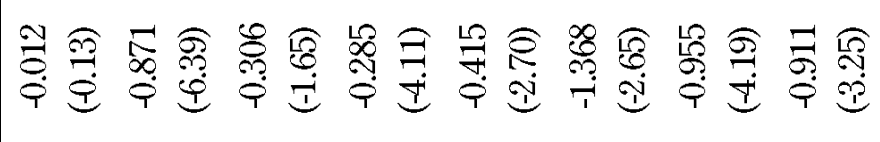 \\
\hline & 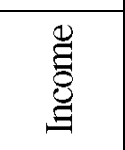 & 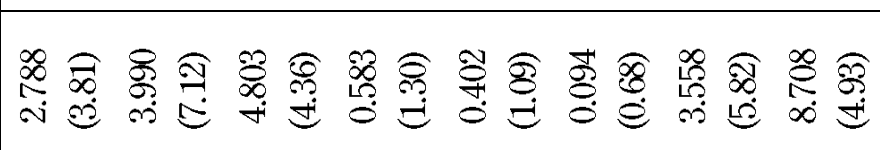 \\
\hline & $\begin{array}{l}\overrightarrow{\bar{F}} \\
\overline{0} \\
\end{array}$ & 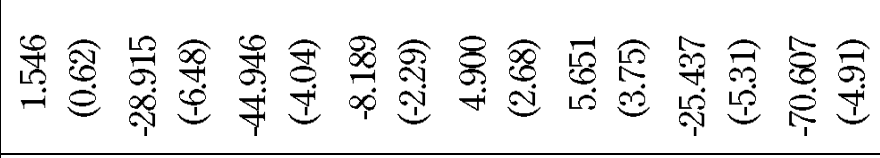 \\
\hline & & \\
\hline
\end{tabular}




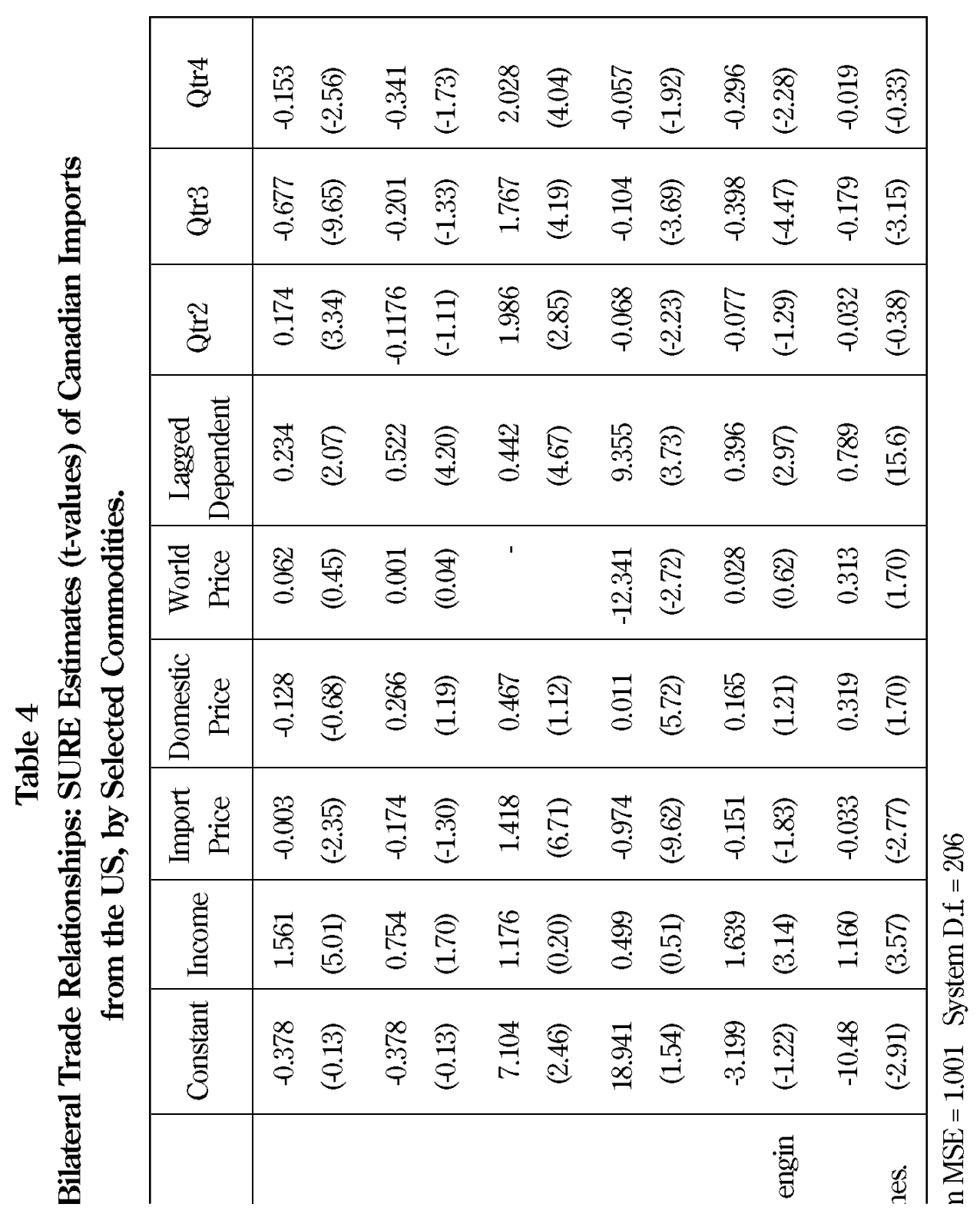




\begin{tabular}{|c|c|c|c|c|c|c|c|}
\hline \multirow{10}{*}{ 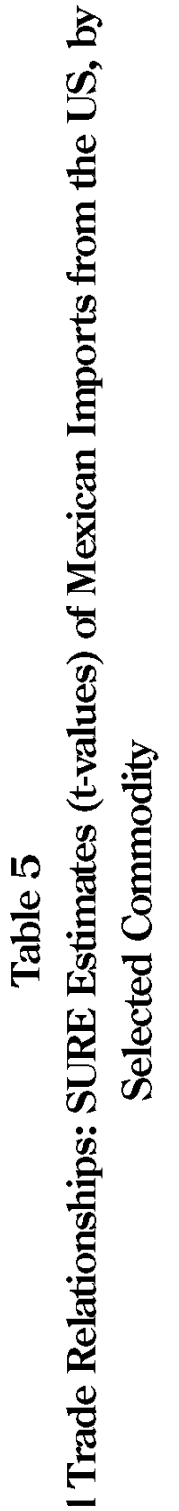 } & $\overrightarrow{0}$ & 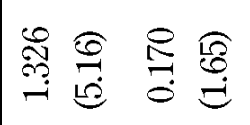 & 氙 & 导点 & 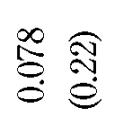 & 高苞 & 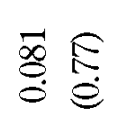 \\
\hline & $\stackrel{\dddot{\theta}}{\theta}$ & 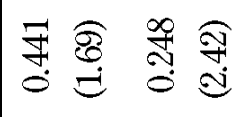 & 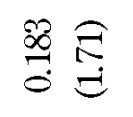 & $\stackrel{0}{\overrightarrow{0}} \stackrel{9}{9}$ & 冚突 & $\begin{array}{l}\stackrel{N}{N} \widehat{S} \\
\stackrel{i}{i}\end{array}$ & $\stackrel{5}{6}$ \\
\hline & 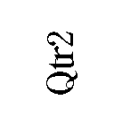 & 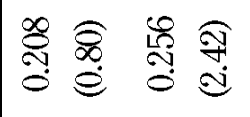 & $\stackrel{E}{E} \stackrel{E}{E}$ & 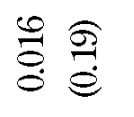 & 施 & 导 & 点 \\
\hline & 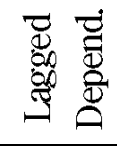 & 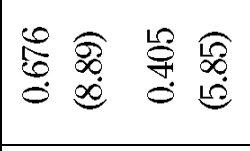 & 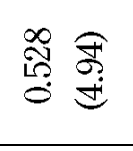 & 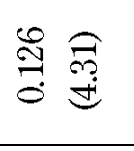 & 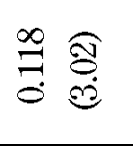 & 㣽兽 & 旅 \\
\hline & 플 & 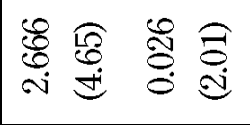 & 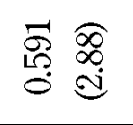 & 臭 & đ్d & $\begin{array}{l}\stackrel{N}{N} \underset{\hat{N}}{\infty} \\
\stackrel{0}{0}\end{array}$ & 疻 \\
\hline & 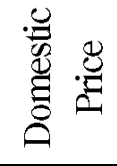 & 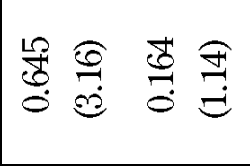 & ' & 䯍 & 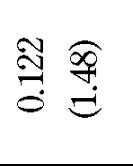 & $\stackrel{\sqrt{0}}{\vec{\sigma}}$ & 蒫 \\
\hline & 䒿 & 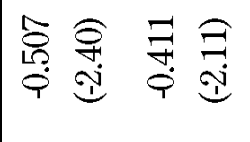 & $\stackrel{\overbrace{}}{\stackrel{\overbrace{}}{: ~}}$ & 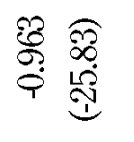 & 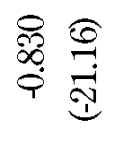 & 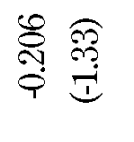 & 㝵 \\
\hline & $\underset{\mathscr{Z}}{\mathscr{E}}$ & 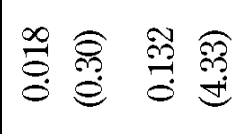 & 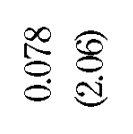 & 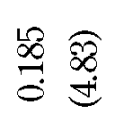 & 冚 & $\stackrel{8}{\stackrel{\mathbb{N}}{d}}$ & 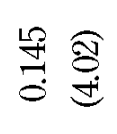 \\
\hline & $\begin{array}{l}\overline{\text { ज्ञ }} \\
\overline{0} \\
\overline{8}\end{array}$ & 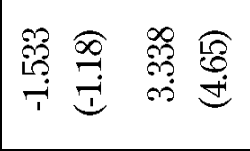 & 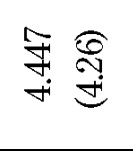 & 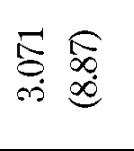 & 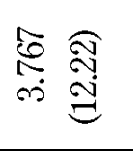 & 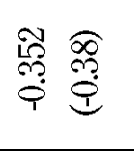 & 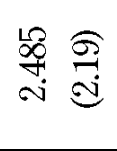 \\
\hline & & & & $\dot{\Xi}$ & & $\underline{\theta}$ & \\
\hline
\end{tabular}




\section{A. The US I mport Demand from Canada and Mexico}

The estimated coefficients of the US import demand models have signs expected signs for most commodities. The price elasticities of US imports from Canada and $M$ exico vary widely across commodities. The magnitude of import price elasticities varies from -0.065 to -1.37 as shown in Tables 2 and 3. Elasticities that are greater than 1.0, in absolute values, indicate relatively high competition for the commodities concerned. Further, relative differences in elasticities between commodity groups indicate relative differences in potential import price responsiveness between the commodity groups. For example, the results in Table 2 suggest that US imports of Vegetables and Fresh Produce from Canada are more sensitive to bilateral import prices $(-0.92)$ than US imports of Refined Petroleum Products from Canada $(-0.33)$. However it is interesting to note that US imports of Crude Oil and Refined Petroleum Products from Canada reflect more competitiveness of US internal market for these products while the other products face a relatively more competitive import markets. In Table 3, US imports from M exico exhibit similar behavior as imports from Canada. However, estimated elasticities indicate relatively higher import price sensitivity for the following commodity groups: Wood Shaped Sleepers; Crude Petroleum; Petroleum Products; Paper and Paperboard; Gas, Natural and M anufactures; and Passenger M otor Vehicles except Buses. M ost US Imports from M exico seems to be more responsive to bilateral price changes than to domestic price changes. This finding contrasts results from past studies that used aggregate trade data, and indicated a domestic markets were more competitive than international markets for all commodity groups 〈e.g., Karemera and Koo [1994]). 
al prices than to domestic prices. The remaining commodities seem to be more sensitive to domestic price changes than to bilateral import prices. This latter result suggests the existence of relatively competitive markets for those domestic products.

\section{Mexican Imports Demand from the US}

M exico has a developing economy with a large internal market. The import price elasticities are less than 1.0, suggesting that imports from the US would face less competition in M exico. However, among commodity groups considered, the commodity groups of Automatic Data Processing Equipment and Television Receivers are relatively more sensitive to bilateral import price changes than to domestic price changes. Unlike imports behaviors in the US and Canada, few M exican import commodities, such as the group of Paper and Paperboard, and Wood Shaped Sleeper, exhibits sensitivity to seasonality. The responsiveness of imports to M exican income change is relatively inelastic for all commodities imported from the US, reflecting the much talked about relative lower income status of $M$ exico visa-vis US and Canada 〈e.g., see Doroodian, et al. [1994]; B rown, et al. [1995]; and Klein and Salvatore, [1995]〉.

Finally, a comparison of the four bilateral import demand models shows that the US and Canada have similar import demand behaviors. Canada and the US are high income countries with comparable technologies. In particular, a rise in international inflation significantly increases M exican imports from the US for most commodities; while the effects of international price changes on US and Canadian imports remain highly commodity specific. For example, Table 5 indicates that a rise in world prices is found to be associated with higher levels of most M exican imports from the US; while the offorte of tho isinrld nriro inflation an tho IIC and $r$ ansdian imnnrte ic aithor 
average imports levels shown in Table 1. The average tariff rates used were obtained from the Harmonized Tariff Schedule of the United States for the selected commodity groups. The Canadian and M exican tariff rates were taken from the US Commerce D epartment's International Trade Division series. TD effects are calculated by using the Verdoorn model in equation \#5. Table 6 (Panel-A, 4th column) shows that, under complete tariff cut following NAFTA, the US imports of both Paper and Paperboard products, and Vegetables and Fresh produce from Canada would increase by $\$ 0.294$ billion and $\$ 0.0065$ billion, respectively. These differing industry-specific trade increases occur in response to the removal of tariff barriers. This outcome is partly due to the replacing of higher cost domestic products with trade partners' imports (i.e., NAFT A's TC effects of $\$ 0.169$ billion and $\$ 0.006$ billion for the Paper Products and Vegetables groups, respectively). The complete removal of trade barriers would equally contribute $\$ 0.125$ billion and $\$ 0.498$ billion, respectively, to the trade increase of the two commodity groups by displacing imports from non NAFTA countries with imports from NAFTA countries (NAFTA's TD effects are reported in the 3rd column). Clearly, TC is greater than TD for essentially all industries, suggesting increased competitive pressures for US firms in those industries.

Similarly, according to Panel-B of Table 6, completely eliminating tariff barriers in the US would increase US imports of Crude Oil from M exico by $\$ 0.106$ billion as a result of TC effects and by $\$ 0.012$ billion as a result of TD effects. The largest increase in Canadian imports from the US would come from the group of Paper and Paperboard products, and would be $\$ 0.031$ billion from TC effects and $\$ 0.018$ billion from TD effects (for a total commodity trade expansion of $\$ 0.049$ billion) under the tariff cut following NAFTA. According to the commodity groups we evaluated for M exico-Canada trade, Electrical Distribution Equipment and Automatic Data Processing Equip- 
Table 6

Potential Trade Creation and Diversion Effects of NAFTA Due to the Removal of Tariff Barriers for Selected Commodity Groups:

A. NAFTA Effects on Selected US Imports from Canada (in 1,000 US \$)

\begin{tabular}{|l|r|r|r|}
\hline Commodity group (SITC) & Trade Creation & Trade Diversion & Trade Expansion \\
\hline Vegetables F resh etc (054) & $6,097.00$ & 498.00 & $6,595.00$ \\
Wood shaped sleepers (248) & $63,149.00$ & $34,579.00$ & $97,728,00$ \\
Pulp and waste paper (251) & $97,122.00$ & $104,875.00$ & $201,997.00$ \\
Crude petroleum (333) & $187,195.00$ & $23,447.00$ & $210,642.00$ \\
Petroleum product, ref. (334) & $36,128.00$ & $5,808.00$ & $41,936.00$ \\
Gas, natural \& manufac. (341) & $129,854.00$ & $89,379.00$ & $219,233.00$ \\
Paper and paperboard (641) & $169,212.00$ & $125,539.00$ & $294,751.00$ \\
Television Receivers (761) & $1,240.00$ & 64.00 & $1,304.00$ \\
TOTAL EFFECTS & $689,997.00$ & $384,189.00$ & $1,074,186.00$ \\
\hline
\end{tabular}

\section{B. NAFTA Effects on Selected US imports from Mexico (in 1,000 US \$)}

\begin{tabular}{|l|r|r|r|}
\hline Commodity group (SITC) & Trade Creation & Trade Diversion & Trade Expansion \\
\hline Vegetables F resh etc (054) & $66,637.00$ & $34,318.00$ & $100,955.00$ \\
W ood shaped sleepers (248) & $5,134.00$ & 113.00 & $5,247.00$ \\
Pulp and waste paper (251) & 106.00 & 0.00 & 106.00 \\
Crude petroleum (333) & $106,805.00$ & $12,123.00$ & $118,928.00$ \\
Petroleum product, ref. (334) & $9,571.00$ & 25.00 & $9,596.00$ \\
Gas, natural \& manufac. (341) & $21,727.00$ & $1,320.00$ & $23,047.00$ \\
Paper and Paperboard (641) & $5,081.00$ & 43.00 & $5,124.00$ \\
Pass. motor veh. except bus (781) & $69,713.00$ & $2,196.00$ & $71,909.00$ \\
TOTAL EFFECTS & $284,774.00$ & $50,138.00$ & $334,912.00$ \\
\hline
\end{tabular}

\section{NAFTA Effects on Selected Canadian Imports from the US (in 1,000 US \$)}




\section{NAFTA E ffects on Selected Canadian Imports from Mexico (in 1,000 US \$)}

\begin{tabular}{|l|r|r|r|}
\hline \multicolumn{1}{|c|}{ Commodity group (SITC) } & Trade Creation & Trade Diversion & Trade Expansion \\
\hline Paper and paperboard (641) & 90.00 & 165.00 & 255.00 \\
Internal combust. pstn. engin. (713) & 111.00 & $5,277.00$ & $5,388.00$ \\
Automatic data proc. equip. (752) & $1,157.00$ & $35,360.00$ & $36,517.00$ \\
Electric. distribt. equip. nes. (773) & 878.00 & $99,317.00$ & $100,195.00$ \\
Electric. mach. appart. nes. (778) & 554.00 & $13,463.00$ & $14,017.00$ \\
Goods, specl. transport veh. (782) & 531.00 & $10,361.00$ & $10,892.00$ \\
TOTAL EFFECTS & $3,321.00$ & $163,943.00$ & $167,264.00$ \\
\hline
\end{tabular}

\section{E. NAFTA E ffects on Selected Mexican Imports from the US (in 1,000 US \$)}

\begin{tabular}{|l|r|r|r|}
\hline Commodity group (SITC) & Trade Creation & Trade Diversion & Trade Expansion \\
\hline Vegetables Fresh etc (045) & $1,959.00$ & $1,689.00$ & $3,648.00$ \\
Wood shaped sleepers (248) & $2,576.00$ & $1,821.00$ & $4,397.00$ \\
Pulp and waste paper (251) & $13,461.00$ & $10,814.00$ & $24,275.00$ \\
Paper and paperboard (641) & $3,640.00$ & $1,428.00$ & $5,068.00$ \\
Automatic data proces. equip. (752) & $18,906.00$ & $7,627.00$ & $26,533.00$ \\
Television receivers (761) & $4,749.00$ & $1,960.00$ & $6,709.00$ \\
Passenger motor veh. (781) & $4,141.00$ & $1,897.00$ & $6,038.00$ \\
Goods, spcl. transport veh. (782) & 604.00 & 415.00 & $1,019.00$ \\
TOTAL EFFECTS & $50,036.00$ & $27,651.00$ & $77,687.00$ \\
\hline
\end{tabular}

\section{F. NAFTA Effects on Selected Mexican Imports from Canada (in 1,000 US \$)}

\begin{tabular}{|l|c|r|r|}
\hline Commodity group (SITC) & Trade Creation & Trade Diversion & Trade Expansion \\
\hline Paper and paperboard (641) & $\$ 518.00$ & $\$ 17,913.00$ & $18,431.00$ \\
Internal combust. pstn. engin. (713) & $\$ 210.00$ & $\$ 3,817.00$ & $4,027.00$ \\
Automatic data proc. equip. (752) & $\$ 31.00$ & $\$ 24.00$ & 55.00 \\
Television receivers etc. (761) & $\$ 2.00$ & $\$ 1.00$ & 3.00 \\
Electric. distribt. equip. nes. (773) & $\$ 16.00$ & $\$ 6.00$ & 22.00 \\
Flertric marh annart nec (778) & $\$ 67 n \cap$ & $\$ 83 \cap 0$ & $150 n$
\end{tabular}


of Television Receivers and Automatic Data Processing Equipment from the US by $\$ 0.004$ billion and $\$ 0.018$ billion respectively from TC effects, and by $\$ 0.001$ billion and $\$ 0.007$ billion respectively from TD effects (see Panel-E).

M exico's largest imports from Canada would occur in the Paper and Paperboard commodity group ( $\$ 0.018$ billion, Panel-F). The TD of this potential trade expansion would be $\$ 0.017$ billion versus TC of $\$ 0.518$ billion, which again corroborates the observation of substantial transhipment trade between Canada and $M$ exico. In fact, a comparison of Panels $A$ and $B$, and Panels $D$ and $F$ seems to suggest that NAFTA would create new trades via US-Canada and US-M exico transactions, and would divert (replace) non NAFTA trades via Canada-M exico transactions.

In general, under a complete removal of tariff barriers, the trade volume of the analyzed commodities examined would experience an increase of $\$ 1.074$ billions in US imports from Canada, and an increase of $\$ 0.334$ billion in US imports from M exico. Canadian imports of the selected commodities from the US and M exico would increase by $\$ 0.063$ billion and $\$ 0.167$ billion, respectively. M exico's imports from the US and Canada would increase by $\$ 0.077$ billion and $\$ 0.028$ billion, respectively. The differences in NAFTA trade effects reflect differences in import demand elasticities and sizes of internal markets among the NAFTA countries. M exico has a larger internal market than Canada, but M exico's price elasticities of import demands are more relatively inelastic than Canada's. Therein lies the explanation of the limited trade gains for Mexico recorded for the early stages of NAFTA's implementation. The US import demand behavior indicates that the US has a higher internal market and higher import market competition than the other NAFTA countries, thus suggesting higher potential trade benefits for the US at the early stages of NAFTA's implementation.

The effects of income change on imports under NAFTA yield mixed 
substantially from the trade area's expanding trade volume (i.e., due to the high absorptive capacity of M exico's large internal market). The preceding deductions from our empirical results do not preclude countries like the US which are supposed to experience short-run NAFTA benefits from experiencing same or more NAFTA benefits in the medium-and/ or long-run. In fact, we expect the income elasticities of imports for M exico to become more important than it appears now when $M$ exico experiences growth in its pool of the middle-class. Perhaps, this growth would come as a result of the initial benefits offered by the implementation of NAFTA.

The foregoing analysis was limited to the ten most traded commodity groups among NAFTA countries. The results suggest differential competitive behavior in domestic and import markets for all commodities in the US, Canada and M exico. A similar analysis may be expanded to other commodities groups.

\section{Conclusion}

Overall, the removal of all tariff barriers from among NAFTA countries would increase NAFTA countries' trade to an estimated tone of about $\$ 2$ billions for the 6-10 most traded commodity groups studied. The estimated trade expansion would occur differently across countries and industries. Some industries would experience trade increase and others would experience trade contraction, notwithstanding the trade area's overall trade increase. Of the three NAFTA countries, US and Canada have developed economies with advanced technologies and similar cultural heritage. M exico is a developing country with less advanced technologies, but it has a large internal market. Thus, the documented price and income elasticities estimates suggest that the US will benefit the most from initial trade 
tries than domestic substitutes are demanded domestically. The income and/ or import price elasticities of individual industries suggest directional impacts of NAFTA that each examined industry should expect. For instance, among the commodities analyzed, the removal of tariff barriers will have greater effects on US imports of Vegetables from Canada, and of Gas, Natural or M anufactures from M exico than other examined imports from these countries. NAFTA effects will be greatest on the Canadian imports of Crude Oil from the US. Automatic Data Processing Equipment, and Television Receivers would be the largest beneficiary industries or commodity groups among US exporters to M exico. Canadian exporters of Paper and Paperboard products would benefit most from trade with M exico, as it would in trade with the US. Furthermore, we document that NAFTA elicits more trade creation than it elicits trade diversion. This suggests NAFTA countries, especially the US and Canada already had in place low tariffs with non NAFTA member countries through various bilateral trade pacts.

In conclusion, it is important to note that our study addresses the static effects of NAFTA by assuming that industry (market) structures in all NAFTA countries remain unchanged. However, in the long run industries should change in adjustment to, for instance, changing availability of resources, evolving market structures, evolving technologies, accession of other Western Hemisphere's countries to NAFTA 〈as suggested by B rown, et al. [1996] and Casario [1996]). These changes may lead to more investments and more trade than expected. That is, in the long run actual effects of NAFTA could turn out to be larger for individual industries and countries than those suggested by our research.

References 
North American Free Trade Agreement: Analytical Issues and a Computational Assessment," The World E conomy, January; pp. 11-29.

Brown, Drusilla K., Alan V. Deardorff, and Robert M. Stern [1995], "Expanding NAFTA: Economic Effects of Accession of Chile and Other South American Nations," The N orth American Journal of E co nomics and Finance 6, No. 2; pp. 148-170.

Casario, M ichelle [1996], "N orth American Free Trade Agreement Bilateral Trade Effects," Contemporary E conomic Policy, XIV; pp. 36-47.

Doroodian, K., Roy G. Boyd, and M atloob Piracha [1994], "A CGE Analysis of the Impact of Trade Liberalization between the US and M exico," Atlantic Economic Journal 22, N o. 4; pp. 43-54.

Goldstein, M orris and M oshkin Khan [1978], "The Supply and Demand for Exports: A Simultaneous Approach," Review of Economics and Statistics, February; pp. 275-286.

International M onetary Fund, International Financial Statistics, various Issues.

Jacobs, Stephen P. [1991], "The NAFTA: Exports, J obs, Wages, and Investment," Business America, October 18; pp. 3-5.

Karemera, David and Won Koo [1994], "Trade Creation and Diversion Effects of the U.S.-Canadian Free Trade Agreement," Contemporary Economic Policy, Vol. XII, January; pp. 12-23.

Klein, Lawrence R. and Dominick Salvatore [1995], "W elfare Effects of the North American Free Trade Agreement," Journal of Policy Modeling 17, No. 2; pp. 163-176.

Koo, Won W., Ihn H. Uhm, and Joel Golz [1991], "Bilateral Trade Relationship Between the United States and Canada: Implications of Free Trade Agreement," Contemporary Policy Issues, October; pp. 56-69.

K oo, Won W, David Karemera, and Richard Taylor [1993], “ A Gravity 
the Baldwin-M urray and Verdoorn M odels," Weltwirtschaftliches Archive; pp. 18-26.

Verdoorn, Petrus ] . and C. A. Van Bochove [1972], "M easuring Integration Effects: A Survey," Economic Review, M arch; pp. 237-49.

Verdoorn, Petrus ] . [1960], "The IntraBloc Trade of B enelux," in Economic Consequences of the Size of Nations, E. A. G. Robinson, ed., M acmillan for the International Economic Association, London.

Wang, George H. K., M ichael Hidiroglou and Wayne Fuller [1981], “Estimation of Seemingly Unrelated Regression with Lagged Dependent Variable and Autocorrelated Errors," Journal of Statistical and Computa tional Simulation, June; pp. 133-145.

Wonnacottt, Ronald and Paul Wonnacott [1982], "Free Trade Between United States and Canada: 15 Years Later," Canadian Public Policy Supple ment, October; p. 7.

Wylie, Peter J. [1995], "Partial Equilibrium Estimates of M anufacturing Trade Creation and Diversion Due to NAFTA," N orth American Jour nal of E conomics and Finance 6, No. 1; pp. 65-84.

Yamazawa, Ippei [1992], “On Pacific Economic Integration," The Economic Journal 102; pp. 1519-1529.

Zellner, A. [ 1962], "An Efficient method of estimating Seemingly Unrelated Regression and Tests of Aggregation Needs," Journal of American Sta tistical Association, June; pp. 348-68. 